\title{
INTRODUCTION
}

\section{The ecology of temperate reefs in a changing world}

\author{
Bayden D. Russell* \\ *The Swire Institute of Marine Science and School of Biological Sciences, The University of Hong Kong, Pok Fu Lam, \\ Hong Kong SAR
}

\begin{abstract}
The world's temperate coastlines support a rich marine biodiversity and provide billions of dollars of ecosystem services to the global economy annually. Temperate coasts are, however, some of the most densely populated and impacted coastal regions of the world and are increasingly modified by a range of local and global impacts. Understanding the natural functioning of these systems, and the impact of human activities, has been the focus of intense research for more than a century. This focus has led to a community of scientists that gathers at the International Temperate Reefs Symposium (ITRS) to share advances in the field. The papers in this Theme Section (TS) are a selection of the research presented at the 12th ITRS in January 2019. The papers cover the breadth of research at the conference, from algal and animal physiology, to population dynamics and range-shifts, the effects of natural and anthropogenic disturbances on systems, and new insights into efforts to mitigate these impacts. These contributions bring together the rich history of the field and enhance our understanding of how these systems will function into the future.
\end{abstract}

KEY WORDS: Temperate reef - Ocean warming - Species range shift · Thermal physiology • Urban shores · Kelp forest · Primary production

\section{INTRODUCTION}

Temperate marine ecosystems have a rich history of study, yet only recently a broader recognition of their global value to human society has developed. Predominantly near-shore systems, temperate reefs are hard-bottomed ecosystems which host a rich diversity of species, often with macroalgal forests as the dominant habitat-formers. Globally, these systems are the basis for billions of dollars of ecosystem services annually, including more traditional uses like commercial and recreational fisheries, but also increasingly tourism (Bennett et al. 2016). More recently, the potential for these systems in oceanbased solutions to climate mitigation through carbon capture and storage (Macreadie et al. 2019, FilbeeDexter \& Wernberg 2020) and blue growth of eco-

${ }^{*}$ Corresponding author: brussell@hku.hk nomies has been noted (Caswell et al. 2020). Temperate reefs are, however, found along some of the most densely populated and impacted coastal regions of the world and are becoming increasingly modified by a range of local and global impacts. Therefore, over the last two decades research in these systems has evolved from developing an understanding of their structure and function to working towards not only understanding the extent of these impacts but also mitigating them.

Given that temperate coastlines are densely populated, support high biodiversity, and provide ecosystem services which drive regional economies, there is a vibrant and active community of researchers involved in understanding their structure and function, and the effects of human activities on their future. This community gathers every 2.5 to 3 years at

(C) The author 2020. Open Access under Creative Commons by Attribution Licence. Use, distribution and reproduction are unrestricted. Authors and original publication must be credited. 
the International Temperate Reefs Symposium (ITRS) to share advances in the field (see Wernberg 2016 for a full list of conferences). The papers in the present Theme Section (TS) are a selection of the research presented at the $12^{\text {th }}$ ITRS hosted at the Swire Institute of Marine Science, The University of Hong Kong, on the $30^{\text {th }}$ anniversary of the first ITRS. Contributions cover a wide range of topics such as the current structure of temperate reef systems, current efforts to enhance the function of urbanised shores, and experimental assessments of how organisms may be affected by future ocean heating and acidification. Papers span all levels of biological organisation from individual to ecosystem.

\section{TROPHIC LINKS AND ENERGY TRANSFER IN TEMPERATE SYSTEMS}

Primary productivity underpins the function of marine ecosystems. Within temperate reef systems this productivity is predominantly driven by macroalgae, which form dense stands or forests from the intertidal through to the deep subtidal. While the productivity of individual species is relatively well studied, the data tend to be from a relatively limited range of environmental conditions. How this productivity integrates into systems over the full spectrum of environmental conditions is, therefore, relatively unknown. Bordeyne et al. (2020, this TS) combine in situ measures and modelling to quantify the productivity of an algal community over an annual cycle. By explicitly incorporating variable light intensity and temperatures into their models, they show that while the community has net production over a year, net respiration in the colder seasons means that extrapolations from measures taken at peak summer productivity would overestimate annual production.

When algal biomass is dislodged from the rocky substrate, it is generally thought to be transported to soft-sediment environments and rapidly enter detrital pathways, therefore no longer contributing to primary productivity (Pederson et al. 2020). This paradigm was overturned by de Bettignies et al. (2020, this TS), who demonstrated that kelp fragments that accumulate within nearshore environments decay slowly and can continue to contribute to productivity in these systems for up to 6 mo after dislodgement. Interestingly, this accumulated drift kelp is inhabited by a diverse macrofaunal community that develops a diverse food web which is distinct from those in adjacent soft sediments and plays an important role in the transport of material into the detritus through trophic transfer (de Bettignies et al. 2020).

Benthic herbivory plays an important role not only in the transfer of energy within food webs but also in structuring and maintaining temperate reef systems. Grazing gastropods can determine the succession of communities (Anderson \& Underwood 1997) and also serve as a compensatory mechanism against ecosystem shifts under altered environmental conditions by consuming algal turfs (Falkenberg et al. 2014, Ghedini et al. 2015). Suzuki et al. (2020, this TS) add to this literature by demonstrating how herbivorous gastropods remove turfs and sediment in heavily impacted systems, thus facilitating the development of macroalgal communities. Eger \& Baum (2020, this TS) place these relationships between benthic herbivory and ecosystem structure and function in a global context, using a meta-analysis of 147 studies to elucidate the strength of top-down control in coastal benthic systems. They found that top-down control is substantially modulated in systems where higher nutrient concentrations or colder temperatures increase net production. Ultimately, however, the largest populations of primary producers (e.g. kelps) occurred in marine reserves where predators reduced herbivore populations (Eger \& Baum 2020).

\section{LOCAL DISTURBANCE AND COMMUNITY STRUCTURE}

There is a long history of research to understand the effects of both natural and anthropogenic disturbances on temperate marine ecosystems. Yet there are sometimes unanticipated natural events, which can advance our understanding; Gerrity et al. (2020, this TS) had a unique opportunity to characterise the devastating effects of an earthquake, which lifted the height of $\sim 140 \mathrm{~km}$ of shore in New Zealand, focussing on populations of pāua (blackfoot abalone). As could be expected, widespread mortality of pāua from their habitat being lifted above sea level removed entire cohorts. However, proactive management through the immediate closure of the fishery and strong recruitment following the earthquake suggest that both pāua populations and the fishery will recover rapidly.

Large-scale damage to ecosystems can also occur because of human activities. Norderhaug et al. (2020, this TS) investigated the ecosystem-level effects of kelp harvesting over areas of $10 \mathrm{~s}$ of $\mathrm{km}^{2}$. Not surprisingly, removal of the primary habitat-forming species at this scale reduced diversity and abundance of species at multiple trophic levels. Importantly, however, 
these results have relevance to not only the management of commercial harvest of this kelp but also provide insights into the potential ecosystem-level effects that could occur if this habitat-former suffers large-scale mortality under climate change (e.g. marine heatwaves; Wernberg et al. 2016).

The propensity of humans to live in coastal areas has resulted in the rapid development of coastlines globally in recent decades (Williams et al. 2016). The introduction of artificial structures along coastlines, in particular concrete walls, destroys natural habitats and has deleterious ecological effects (Thompson et al. 2002, Huang et al. 2015). Acknowledging that coastal development is likely to continue into the future, focus has shifted towards understanding how to improve the ecological value of manmade structures. One of the more commonly used eco-engineering techniques to improve the 'value' of walls is to incorporate or retrofit tiles which introduce greater habitat complexity (O'Shaughnessy et al. 2020). Taira et al. (2020, this TS) demonstrate that such ecoengineering can not only improve habitats for benthic species (Strain et al. 2018) but that enhancement of food resources increases the diversity and abundance of fish through strengthened trophic links (Taira et al. 2020). Aside from the physical structure, the concrete in seawalls is generally thought to be an inferior substrate for marine organisms because of its chemical properties. It has been suggested that the high surface $\mathrm{pH}$ of concrete $(\sim 13)$ might inhibit the development of sessile communities and that concrete with a $\mathrm{pH}$ closer to that of seawater $(\sim 8)$ could enhance diversity on seawalls (e.g. Perkol-Finkel \& Sella 2014). Hsiung et al. (2020, this TS) provide the first evidence that this thinking may be wrong. They experimentally demonstrate that low-pH concrete does not enhance abundance or species richness of organisms on seawalls in temperate or tropical systems. Therefore, while there are environmental benefits to low-pH concrete, in particular substantially lower carbon emissions, there is currently little evidence that they will enhance biodiversity on seawalls any more than other eco-engineering approaches.

\section{RESPONSES TO GLOBAL HEATING}

The consequences of global climate change will manifest from individual physiological to population levels, and only by integrating these effects can we predict the potential changes in biological communities (Russell \& Connell 2012). Extreme events such as marine heatwaves can cause devastating effects on ecosystems (e.g. Wernberg et al. 2016). With longerterm ocean heating, however, the physiological plasticity and ability of individuals to acclimate to hotter temperatures will determine the structure of communities. For example, the capacity of different species that coexist in the same habitat to tolerate hotter temperatures will determine which species are more or less likely to acclimate and persist (Leung et al. 2019). The biological performance of a species is generally thought to be reduced closer to the warm edge of its distribution and will decline further with warming. In contrast, Oróstica et al. (2020, this TS) show that performance can be more nuanced, with performance being determined by not only position in the geographical distribution but also population density and location-specific conditions. Over decades of warming, these differences in physiology can manifest at the community level (Mulders \& Wernberg 2020, this TS), with more temperature-tolerant species, or those which can recover faster, persisting (Hemraj et al. 2020). However, not all population responses reflected latitudinal gradients but rather were influenced by more local conditions (Mulders \& Wernberg 2020) as found by Oróstica et al. (2020). Therefore, any such changes in performance and survival that manifest differentially across taxa sharing functional roles (e.g. benthic grazers; Minuti \& Russell 2020, this TS) or across tropic levels (Mertens et al. 2015) are likely to underpin changes that will propagate throughout the ecosystem.

\section{CONCLUSIONS}

The papers which form this TS cover the spectrum of knowledge needed to understand the function of temperate reef systems not only under current conditions but also into the future. They represent both the foundational ecological knowledge and the advances in individual to population-level research to help inform managers and policy makers on how to best protect the future of these systems.

Acknowledgements. I would like to acknowledge the efforts of the Guest Editors and the Editorial Staff at MEPS in completing this Theme Section. The 12th International Temperate Reefs Symposium (ITRS) was only possible because of the tireless work of my co-organizer, G. A. Williams, scientific organizing committee (L. Firth, Y.-W. Dong, D. A. Hemraj, T. T. Y. Hui, S. Crickenberger), the staff and students of The Swire Institute of Marine Science, and the administrative staff of the School of Biological Sciences, University of Hong Kong. ITRS was sponsored by HKU Faculty of Science, Swire Coca-Cola HK, and IR Marine Ecology Progress Series. A 
conference is only as good as the research community which supports it. ITRS has been attended by a passionate group of scientists and friends for 30 years, leading to hot debate and scientific advances, but above all camaraderie. Thank you all.

\section{LITERATURE CITED}

Anderson MJ, Underwood AJ (1997) Effects of gastropod grazers on recruitment and succession of an estuarine assemblage: a multivariate and univariate approach. Oecologia 109:442-453

Bennett S, Wernberg T, Connell SD, Hobday AJ, Johnson CR, Poloczanska ES (2016) The 'Great Southern Reef': social, ecological and economic value of Australia's neglected kelp forests. Mar Freshw Res 67:47-56

Bordeyne F, Migné A, Plus M, Davoult D (2020) Modelling the annual primary production of an intertidal brown algal community based on in situ measurements. Mar Ecol Prog Ser 656:95-107

Caswell BA, Klein ES, Alleway HK, Ball JE and others (2020) Something old, something new: historical perspectives provide lessons for blue growth agendas. Fish Fish 21: 774-796

de Bettignies F, Dauby P, Lepoint G, Riera P and others (2020) Temporal succession of a macrofaunal community associated with kelp fragment accumulations in an in situ experiment. Mar Ecol Prog Ser 656:109-121

Eger AM, Baum JK (2020) Trophic cascades and connectivity in coastal benthic marine ecosystems: a meta-analysis of experimental and observational research. Mar Ecol Prog Ser 656:139-152

Falkenberg LJ, Connell SD, Russell BD (2014) Herbivory mediates the expansion of an algal habitat under nutrient and $\mathrm{CO}_{2}$ enrichment. Mar Ecol Prog Ser 497:87-92

Filbee-Dexter K, Wernberg T (2020) Substantial blue carbon in overlooked Australian kelp forests. Sci Rep 10:12341

Gerrity S, Alestra T, Fischman HS, Schiel DR (2020) Earthquake effects on abalone habitats and populations in southern New Zealand. Mar Ecol Prog Ser 656:153-161

Ghedini G, Russell BD, Connell SD (2015) Trophic compensation reinforces resistance: herbivory absorbs the increasing effects of multiple disturbances. Ecol Lett 18:182-187

Hemraj DA, Posnett NC, Minuti JJ, Firth LB, Russell BD (2020) Survived but not safe: marine heatwave hinders metabolism in two gastropod survivors. Mar Env Res 162:105117

Hsiung AR, Tan WT, Loke LHL, Firth LB and others (2020) Little evidence that lowering the $\mathrm{pH}$ of concrete supports greater biodiversity on tropical and temperate seawalls. Mar Ecol Prog Ser 656:193-205

Huang XW, Wang W, Dong YW (2015) Complex ecology of China's seawall. Science 347:1079

Leung JYS, Russell BD, Connell SD (2019) Adaptive responses of marine gastropods to heatwaves. One Earth $1: 374-381$

Macreadie PI, Anton A, Raven JA, Beaumont N and others (2019) The future of Blue Carbon science. Nat Commun 10:3998

Mertens NL, Russell BD, Connell SD (2015) Escaping herbivory: ocean warming as a refuge for primary produc- ers where consumer metabolism and consumption cannot pursue. Oecologia 179:1223-1229

Minuti JJ, Russell BD (2020) Functionally redundant herbivores: urchin and gastropod grazers respond differently to ocean warming and rising $\mathrm{CO}_{2}$. Mar Ecol Prog Ser 656:239-251

*Mulders YR, Wernberg T (2020) Fifteen years in a global warming hotspot: changes in subtidal mobile invertebrate communities. Mar Ecol Prog Ser 656:227-238

*Norderhaug KM, Filbee-Dexter K, Freitas C, Birkely SR and others (2020) Ecosystem-level effects of largescale disturbance in kelp forests. Mar Ecol Prog Ser 656:163-180

Oróstica MH, Hawkins SJ, Broitman BR, Jenkins SR (2020) Performance of a warm-water limpet species towards its poleward range edge compared to a colder-water congener. Mar Ecol Prog Ser 656:207-225

O'Shaughnessy KA, Hawkins SJ, Evans AJ, Hanley ME and others (2020) Design catalogue for eco-engineering of coastal artificial structures: a multifunctional approach for stakeholders and end-users. Urban Ecosyst 23: 431-443

* Pedersen MF, Filbee-Dexter K, Norderhaug KM, Fredriksen S, Frisk NL, Fagerli CW, Wernberg T (2020) Detrital carbon production and export in high latitude kelp forests. Oecologia 192:227-239

Perkol-Finkel S, Sella I (2014) Ecologically active concrete for coastal and marine infrastructure: innovative matrices and designs. In: Allsop W, Burgess K (eds) From sea to shore-meeting the challenges of the sea. ICE Publishing, London, p 1139-1149

Russell BD, Connell SD (2012) Origins and consequences of global and local stressors: incorporating climatic and non-climatic phenomena that buffer or accelerate ecological change. Mar Biol 159:2633-2639

Strain EMA, Olabarria C, Mayer-Pinto M, Cumbo V and others (2018) Eco-engineering urban infrastructure for marine and coastal biodiversity: Which interventions have the greatest ecological benefit? J Appl Ecol 55: 426-441

Suzuki H, Kubo Y, Inomata E, Agatsuma Y, Aoki MN (2020) Effects of herbivorous gastropod grazing on the sedimentation and succession of subtidal macroalgal assemblages. Mar Ecol Prog Ser 656:123-138

* Taira D, Heery EC, Loke LHL, Teo A, Bauman AG, Todd PA (2020) Ecological engineering across organismal scales: trophic-mediated positive effects of microhabitat enhancement on fishes. Mar Ecol Prog Ser 656:181-192

Thompson RC, Crowe TP, Hawkins SJ (2002) Rocky intertidal communities: past environmental changes, present status and predictions for the next 25 years. Environ Conserv 29:168-191

Wernberg T (2016) Celebrating 25 years of temperate reef science. Mar Freshw Res 67:i-viii

*Wernberg T, Bennett S, Babcock RC, de Bettignies T and others (2016) Climate-driven regime shift of a temperate marine ecosystem. Science 353:169-172

Williams GA, Helmuth B, Russell BD, Dong YW, Thyiagarajan V, Seuront L (2016) Meeting the climate change challenge: pressing issues in southern China and SE Asian coastal ecosystems. Reg Stud Mar Sci 8:373-381 